\title{
Organizational and managerial approach to the energy management system in a company
}

\author{
Anna Minnullina, ${ }^{1, *}$, and Elena Savoskina ${ }^{2}$ \\ ${ }^{1}$ Tyumen Industrial University, Volodarskogo St., 38, Tyumen, 625000, Russia \\ ${ }^{2}$ Samara State Technical University, Molodogvardeyskaya street, 244, Samara, Russia
}

\begin{abstract}
The paper discusses the key areas for improving the energy efficiency of companies both at the stage of implementing the energy management system and as part of its improvement. Within the framework of the organizational and management approach, the deadlines and responsible persons for the implementation of measures for the introduction and operation of the energy management system were developed, and a matrix of distribution of organizational and management tasks was proposed, which gives a description of the degree of participation of each unit in the implementation of energy management activities in a company.
\end{abstract}

\section{Introduction}

In recent years, Russia has taken an active position in the development of energy saving and improvement of energy efficiency. Allocation of such a priority direction of the national development is caused by the need to reduce the burden on the environment in terms of the consumption of fuel and energy resources and the increasing demands for energy efficiency in the world. Improving the energy efficiency of the Russian economy by rationalizing energy consumption, using energy-saving technologies and equipment is one of the main strategic guidelines of the Energy Strategy of Russia for the period up to 2030 approved on November 13, 2009. The most significant national initiative in this area was the adoption of the Federal Act No. 261 dated 11.23.2009 "On energy saving and on increasing energy efficiency and on introducing amendments to certain legislative acts of the Russian Federation" regulating mandatory requirements for energy efficiency to key business entities providing conditions for their implementation $[1,2]$.

The annual monitoring of the results of implementation provided for by the Energy Strategy of Russia shows that, in general, the main quantitative parameters of the development of the fuel and energy sector reach the established ranges of values. However, a number of indicators are not being fulfilled, and even the opposite trends to those expected have established - in particular, with regard to the reduction in the energy intensity of the national economy, there is a lag behind the control strategic indicators. That was taken into account in the draft Energy Strategy of Russia for the period up to 2035 [1, 2].

\footnotetext{
* Corresponding author: minnullinaay@yandex.ru
} 
The creation and implementation of an energy management system in Russian companies can help ensure positive dynamics of energy efficiency, identify and use reserves for managing the rational consumption of fuel and energy resources. The formation of energy management systems is a priority for improving the energy efficiency of Russian companies, in particular, the areas of industrial business.

The problem of energy saving is one of the most actively studied in global science, including Russian. The implementation of the concept of sustainable development, the global importance of which has increased in recent years, the popularization of its ideas and fundamental principles make it necessary to conduct more in-depth studies in the field of improving the energy efficiency of the world economy. It becomes quite obvious that this direction needs to be studied multilaterally, since it is a complex task requiring the application of multidirectional scientific knowledge. The unifying platform for solving the problem of increasing the energy efficiency of an industry is research in the field of energy management, since only competent management methodological solutions can ensure the interaction of its engineering, technological, industrial, economic, organizational, managerial, psychological, social and other aspects.

In recent years, the published results of scientific research are increasingly covering the issues of energy saving in the framework of the functioning of energy management systems and the problems of using energy management as a tool to improve environmental safety and energy efficiency of enterprises. The problems of interpreting the requirements of international standards in the field of energy management, their adaptation and creating the necessary conditions for implementation in the Russian practice are considered in the works by such scientists as Khokhlyavin, Kudryavtsev, Shchelokov, Khorobrykh, Vorobiev, Sklyarov, Marchenko, Akhmetova, Makarov, Marchenko, Farkhutdinov, Osadchiev, Fadeyeva, Pichugin, Lukinov, Syschikov, Tarasovsky, Syusyukin, Yeremeyeva, Shishkina, Kuznetsov and others [3-11].

\section{Methods}

As a result of the analysis of a sufficient number of works [1-4] on the issues of the company's energy management, it is possible to summarize and systematize the key areas for improving energy efficiency (Figure 1).

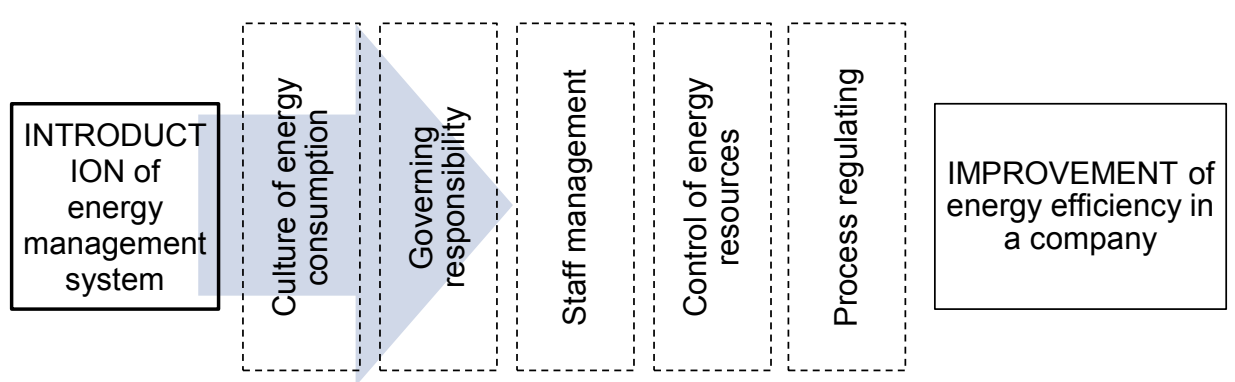

Fig. 1. Main directions in a company's energy management system.

Now coming to describe in more detail each of the elements of the energy management system presented in Figure 1.

An important direction in the energy management of enterprises is the staff's understanding of the possible results of energy saving due to increased consumption culture. Many consumers have no idea which effects can be achieved and what is the result of excessive energy consumption. It is necessary to notify staff using simple examples with 
obligatory percentage or cost voicing of saving, for more complete assimilation of the intended results by the target audience.

Some measures that can provide significant energy savings at enterprises include: installation of an automated lighting system, regular wiping of glazed electrical equipment, installation of an air pressure regulator, etc.

According to the international experience, any process should have control and consolidation of functions of responsibility for staff. Thus, for a competent development of the energy saving process, a target goal by the management is necessary, namely, the documented responsibility of the company's management in achieving the planned level of energy saving and energy efficiency.

It is most expedient to determine the responsibility of the CEO following the results of the implementation of planned performance indicators for the previous period in this direction and the approval of energy efficiency indicators for the current year. Moreover, the motivational component of the CEO should be reflected in the employment contract, thereby documenting the process. In addition, the employment contract of the CEO should also reflect the requirements for energy saving and energy efficiency, which must be achieved for a certain period of time. These include:

- development of the company's strategic goal in the field of energy saving;

- setting strategic and operational tasks in the field of energy saving;

- determination of responsibility, authority and order of staff cooperation;

- energy research plan;

- creating / updating an energy management program;

- maintaining the energy management program at the relevant level;

- monitoring of energy management tasks.

The CEO, in turn, must determine the list of persons who are most fully involved in the processes of energy management, and document their responsibility in the same way.

The study leads to the conviction that until the top manager is responsible for the energy efficiency of the company, the effectiveness of this direction will not be achieved, since it is the top manager who is the main decisive authority in the corporate operation. Moreover, the responsibility of the top manager should be clearly regulated and controlled by business owners in meeting all the requirements of energy saving and energy efficiency, which should result in a reduction in energy consumption.

The development and implementation of energy management programs and activities largely depend on the skill level of the staff involved in this process. Today, as a rule, staff commitment is not enough to maintain enterprises at a level that meets modern requirements. This is due to the fact that in the development of measures it now becomes necessary to:

- $\quad$ calculate the planned energy savings;

- $\quad$ assess the technical potential of implementations / updates, taking savings into account

- $\quad$ evaluate the economic effect of the proposed activities.

Detailed substantiation of the proposed measures will allow making informed decisions within the framework of energy management and, of course, requires highly skilled workers. The main difficulty lies in the fact that the process of energy saving and energy efficiency should involve as many employees as possible, directly or indirectly influencing the improvement of the effectiveness in this area of work. Therefore, staff training in modern methods to achieve these results should be more intensive, multidirectional and carried out on an ongoing basis.

When developing a plan of measures to improve the qualifications of the company's staff, it is advisable to initially distinguish between professional directions of employees, 
then identify those problematic points of energy conservation that lie within staff's area of responsibility.

Also, the problem of choosing an adequate method of staff training requires special attention. In this regard, two principal approaches can be proposed (Table 1).

Table 1. Approaches to staff training.

\begin{tabular}{|l|l|l|}
\hline \multicolumn{1}{|c|}{ Approach } & \multicolumn{1}{c|}{ Application } & \multicolumn{1}{c|}{ Description } \\
\hline $\begin{array}{l}\text { intensive team } \\
\text { training for } \\
\text { employees of } \\
\text { different units } \\
\text { solving related } \\
\text { energy tasks }\end{array}$ & $\begin{array}{l}\text { applicable to the activities of } \\
\text { enterprises with a small } \\
\text { number of staff or rather } \\
\text { large enterprises, but not } \\
\text { working within the } \\
\text { organizational group } \\
\text { structures }\end{array}$ & $\begin{array}{l}\text { training is carried out by professional } \\
\text { consulting firms on the job; } \\
\text { cost method; } \\
\text { allows obtaining the necessary } \\
\text { production experience aimed at } \\
\text { solving specific energy problems; } \\
\text { requires periodic updates }\end{array}$ \\
$\begin{array}{l}\text { experience between } \\
\text { employees of } \\
\text { different enterprises }\end{array}$ & $\begin{array}{l}\text { advisable to be applied by } \\
\text { enterprises that have } \\
\text { branches or other } \\
\text { organizational networks with } \\
\text { other enterprises. }\end{array}$ & $\begin{array}{l}\text { a fast and efficient method; } \\
\text { identified deficiencies are promptly } \\
\text { developed by staff of another branch, } \\
\text { and corrected; } \\
\text { has a cyclical nature }\end{array}$ \\
\hline
\end{tabular}

The need for continuous and effective training of staff in the field of energy saving and energy efficiency is also caused by the fact that after evaluating the economic efficiency, all measures recommended for implementation are classified according to three criteria:

1) low-cost - carried out in the course of the current enterprise operation;

2) average cost - carried out, as a rule, at the expense of own funds of enterprises;

3) high-cost - requiring additional investment.

The ranking of activities for implementation is usually planned in the following order: the activities that are possible to implement at own expense are initially carried out, followed by those requiring additional investment.

High-cost measures usually require more time to calculate the economic efficiency of the project, since it is necessary to more constructively calculate the possible risks and deviations. It is obvious that it is impossible to conduct such calculations without trained highly qualified staff.

An important aspect in improving the energy efficiency of enterprises is the introduction of an energy manager's position in the organizational structure. Today, only the most progressive-minded corporate CEOs are concerned with this issue, and even ready-made specialists in this field are still completely inadequate due to the recent emergence of such a line of professional activity. The search and implementation by energy managers of efficient energy saving measures, the organization of a system for managing energy savings, the development and implementation of energy management systems are all highly relevant areas for improving the activities of Russian enterprises, a necessary condition for their competitiveness today and for the future.

A modern energy manager is a hired, professionally trained top manager or manager, who has a subordinate group of employees occupying a full-time position, empowered in the field of energy use and energy efficiency to make decisions and manage resources, and being responsible for achieving the final results of an enterprise. Some enterprises are developing comprehensive energy efficiency programs, and under the leadership of the energy manager, project participants are implementing this system in the enterprise's operation [12].

The task of the energy manager is to develop the company's energy strategy, which previously did not exist at all, or requires improvement, as does not take into account all the data and is inefficient, which is the most common case. This position is also a novelty for most Russian enterprises. The employee who occupies it is fully responsible for the 
management of the company's energy system, and is engaged in the rational use of energy resources. It must be said that there are practically no ready-made energy management specialists at the present time, their training is just beginning in the relevant educational institutions. Meanwhile, to build a modern energy management system without such a specialist is extremely difficult. This is an employee whose management skills are combined with a set of specific knowledge on energy efficiency.

A rather important area will be the training of energy managers, as at the enterprises there are usually no ready-made specialists. There are special courses for training employees for the positions of energy managers. In recent years, special centers have been organized that train energy managers as top-level specialists in the management of an enterprise.

The specific responsibilities of the energy manager should include: developing an energy management strategy for an enterprise, drawing up a fuel and energy balance, determining the efficiency of energy consumers, controlling investment in energy efficiency measures, conducting an internal energy audit, creating an energy consumption record system, etc. This is not a complete list of the duties of the energy manager. Generally speaking, his/her task is to ensure that divisions of the enterprise, rationally using energy resources, at the same time can effectively and safely implement production tasks. The result of the energy manager's work should be:

- minimizing energy losses;

- optimal mode of production facilities operation;

- increased level of energy efficiency in production;

- reducing energy costs.

Documenting all the procedures, requirements, processes at an enterprise aimed at energy saving is also an important direction in energy management. It is necessary to document specific technical and technological processes, actions at workplaces, etc. Such documents include: rules of the staff; rules of equipment operation in energy-efficient mode and standby mode; rules of household appliances operation; rules for the use of parameter charts, etc.

All information must be documented, public, accessible and regularly reminded. It is necessary to openly post all information with regards to energy saving: results, awards, activities carried out on the official corporate websites, on information boards, to make publications in corporate magazines, etc. It can be noted that this is low-cost, which means available absolutely any company.

Justifying the direction of improving energy efficiency at an enterprise, low-cost activities that are accessible to almost all enterprises and do not require large financial investments were focused on. Based on the above material, it can be concluded that cost reduction can be achieved not only through technical re-equipment, reconstruction and replacement, but also through the formation of proper consumer behavior and the creation of competent management policies.

\section{Results}

To build a streamlined work to continuously improve energy efficiency, it is necessary to implement an energy management system.

The process of implementing an energy management system is proposed to be performed in five stages:

1. preparation and training of the performing staff;

2. documentation update;

3. changing the organizational structure of the enterprise;

4. pilot operation of the energy management system; 
5. analysis of the functioning of the energy management system.

It is possible to consider the energy management system finally implemented only when it passes the pilot stage of operation, and when analyzing the final results of its implementation, there will be no inconsistencies that require improvement and elimination $[13,14,15]$.

All ongoing activities in the framework of the energy management should be described in detail and be accompanied by the indication of the persons in charge, the deadline of implementation, the cost and sources of funding for each event.

In this regard, deadlines and persons in charge for the activities in the framework of implementation and functioning of the energy management system (Table 2) have been developed.

Table 2. Recommended deadlines and persons in charge for the implementation of activities in the framework of the energy management system.

\begin{tabular}{|c|c|c|}
\hline Activity & Deadline & Persons in charge \\
\hline $\begin{array}{c}\text { Order on the introduction / update of } \\
\text { the energy management system }\end{array}$ & 5 working days & $\begin{array}{c}\text { Chief engineer / Deputy } \\
\text { Director for operations }\end{array}$ \\
\hline Staff training & Within 40 working days & Energy manager \\
\hline $\begin{array}{c}\text { Development / update of documents } \\
\text { governing the energy management } \\
\text { measures }\end{array}$ & Under 40 working days & Energy manager \\
\hline $\begin{array}{c}\text { Approval of the governing } \\
\text { documentation }\end{array}$ & 5 working days & Energy manager \\
\hline $\begin{array}{c}\text { Bringing the documentation to the } \\
\text { attention of staff }\end{array}$ & 5 working days & Energy manager \\
\hline $\begin{array}{c}\text { Analysis of the implementation of the } \\
\text { energy management measures }\end{array}$ & Within 12 calendar \\
months & Energy manager \\
\hline $\begin{array}{c}\text { Formalizing analysis results as a } \\
\text { report }\end{array}$ & 5 working days & Energy manager \\
\hline $\begin{array}{c}\text { Formation of a plan to improve the } \\
\text { energy management system }\end{array}$ & Under 40 working days \\
\hline
\end{tabular}

For such events as bringing the approved documentation to the attention of staff, approving the order on the introduction of the energy management system and approving the updated documentation, the same maximum period is set to increase the discipline of both company employees and top management.

The extra day of delay entails additional costs due to not making management decisions aimed at saving energy and increasing energy efficiency. It should also be noted that the consumers of the reports are the top managers of the company, based on which management decisions are made.

Analysis of any indicators of the functioning of the energy management system, financial or economic, is carried out based on the results of work for the month, quarter, half-year, and year. Therefore, in order to understand the effectiveness of the functioning of a process, resulting from the introduction of the energy management system, it is necessary to at least compare the dynamics in each period.

In the process of implementing the energy management system, it is advisable to develop a matrix for the distribution of organizational and managerial tasks for the implementation of the measures described in Table 2 (Table 3). 
Table 3. Matrix for the distribution of organizational and managerial tasks for the implementation of the energy management measures.

\begin{tabular}{|c|c|c|c|c|c|}
\hline \multirow[b]{2}{*}{ Measure } & \multicolumn{5}{|c|}{ Workgroup } \\
\hline & $\begin{array}{l}\text { Chief engineer } \\
\text { / Deputy } \\
\text { Director for } \\
\text { operations }\end{array}$ & $\begin{array}{l}\text { Energy } \\
\text { manager }\end{array}$ & $\begin{array}{l}\text { Financial } \\
\text { department }\end{array}$ & $\begin{array}{l}\text { Engineering } \\
\text { control } \\
\text { department }\end{array}$ & $\begin{array}{c}\text { Purchasing and } \\
\text { supply } \\
\text { department }\end{array}$ \\
\hline $\begin{array}{l}\text { Order on the } \\
\text { introduction / } \\
\text { update of the } \\
\text { energy } \\
\text { management } \\
\text { system }\end{array}$ & Approval & $\begin{array}{c}\text { Approval } \\
\text { Participation } \\
\text { Development }\end{array}$ & Implementation & Implementation & Implementation \\
\hline Staff training & Approval & $\begin{array}{c}\text { Approval } \\
\text { Participation } \\
\text { Development }\end{array}$ & Implementation & Implementation & Implementation \\
\hline $\begin{array}{l}\text { Development / } \\
\text { update of } \\
\text { documents } \\
\text { governing the } \\
\text { energy } \\
\text { management } \\
\text { measures }\end{array}$ & Approval & $\begin{array}{c}\text { Approval } \\
\text { Participation } \\
\text { Development }\end{array}$ & $\begin{array}{l}\text { Development } \\
\text { Implementation }\end{array}$ & $\begin{array}{l}\text { Development } \\
\text { Implementation }\end{array}$ & $\begin{array}{l}\text { Development } \\
\text { Implementation }\end{array}$ \\
\hline $\begin{array}{l}\text { Approval of } \\
\text { the governing } \\
\text { documentation }\end{array}$ & Approval & Approval & - & - & - \\
\hline $\begin{array}{l}\text { Bringing the } \\
\text { documentation } \\
\text { to the attention } \\
\text { of staff }\end{array}$ & - & Participation & Participation & Participation & Participation \\
\hline $\begin{array}{l}\text { Analysis of the } \\
\text { implementation } \\
\text { of the energy } \\
\text { management } \\
\text { measures }\end{array}$ & - & $\begin{array}{c}\text { Approval } \\
\text { Participation }\end{array}$ & Development & Development & Development \\
\hline $\begin{array}{l}\text { Formalizing } \\
\text { analysis results } \\
\text { as a report }\end{array}$ & Approval & $\begin{array}{l}\text { Participation } \\
\text { Development }\end{array}$ & $\begin{array}{l}\text { Participation } \\
\text { Development }\end{array}$ & $\begin{array}{l}\text { Participation } \\
\text { Development }\end{array}$ & $\begin{array}{l}\text { Participation } \\
\text { Development }\end{array}$ \\
\hline $\begin{array}{l}\text { Formation of a } \\
\text { plan to } \\
\text { improve the } \\
\text { energy } \\
\text { management } \\
\text { system }\end{array}$ & Approval & $\begin{array}{c}\text { Approval } \\
\text { Participation }\end{array}$ & $\begin{array}{l}\text { Development } \\
\text { Implementation }\end{array}$ & $\begin{array}{l}\text { Development } \\
\text { Implementation }\end{array}$ & $\begin{array}{l}\text { Development } \\
\text { Implementation }\end{array}$ \\
\hline
\end{tabular}

In general, the matrix of distribution of organizational and management tasks gives a description of the degree of participation of each unit in the implementation of energy management activities at the enterprise. The company's management performs only the role of the regulator, which carries out the procedure of consents and approvals. In addition to controlling the set of documents, the energy manager, before their receipt for approval, still actively participates in all events and is primarily in charge for all processes. As for the other working groups, each of them has the same role in all processes - development / implementation / participation.

\section{Conclusions}

Justifying the directions of improving energy efficiency at the enterprise, low-cost activities that are accessible to almost all enterprises and do not require large financial investments were focused on. Cost reduction can be achieved not only through technical re-equipment, 
reconstruction and replacement, but also through the formation of proper consumer behavior and the creation of competent management policies.

In particular, the proposed distribution matrix of organizational and managerial tasks is easily applicable at any enterprise and gives a description of the degree of participation of each division in the implementation of energy management measures at the enterprise. At the same time, this matrix clearly shows that the main role of the performer is assigned to the energy manager, which emphasizes the need for highly qualified personnel to achieve the goals and objectives of the energy management system.

\section{References}

1. Yu. Kudryavtseva, Current requirements for energy management 2(48), 18-20 (2011)

2. G. Marchenko, Proceedings of higher educational institutions, Energy issues 9-10, 135140 (2012)

3. I. Nemirovsky, Energy: economy, technology, ecology 2(36), 33-38 (2014)

4. A. Minnullina. IOP Conference Series: Earth and Environmental Science 90, 012089 (2017) doi:10.1088/1755-1315/90/1/012089

5. A. Osadchiev, Certification 1, 12-16 (2012)

6. L. Pichugin, Construction and reconstruction, 6, 82-87 (2013)

7. S. Hohlyavin, Energy audit 4(20), 26-31 (2011)

8. R. Farkhutdinov, Proceedings of higher educational institutions. Energy issues 5-6, 92 (2014)

9. N. Shishkin, Human Science: Humanitarian Studies 2(12), 63-66 (2013)

10. N. Zotkina, M. Gusarova, A. Kopytova, Advances in Intelligent Systems and Computing 692, 1204-1213 (2018) DOI: 10.1007/978-3-319-70987-1_129

11. V. Lezier, M. Gusarova, A. Kopytova, IOP Conference Series: Earth and Environmental Science 90(1), 012069 (2017) DOI: 10.1088/1755-1315/90/1/012069

12. A.V. Kopytova, MATEC Web of Conferences 106, 08056 (2017) DOI: $10.1051 /$ matecconf/201710608056

13. A.V. Kopytova, Exchange of intellectual property 3(XIV), 31-37 (2015)

14. A. Minnullina, MATEC Web of conference 106, 08067 (2017) doi: 10.1051/matecconf/201710608067

15. A. Minnullina, R. Abdrazakov, Advances in Intelligent Systems and Computing 692, 1224-1233 (2018) doi: 10.1007/978-3-319-70987-1 131 